\title{
Regulated Deficit Irrigation Effect on Yield and Wine Color of Cabernet Sauvignon in Central California
}

\author{
Michael J. Costello ${ }^{1}$ and W. Keith Patterson \\ Horticulture and Crop Science Department, California Polytechnic State \\ University, 1 Grand Avenue, San Luis Obispo, CA 93407 \\ Additional index words. Vitis vinifera, vineyard, grape, water stress
}

\begin{abstract}
Regulated deficit irrigation (RDI) is a management strategy that on grape can improve shoot/fruit ratio, water efficiency, and wine quality but has the potential to reduce yield. As part of a study on the influence of RDI on leafhopper density, we evaluated the effects on grape yield, berry size, berry soluble solids, and wine color. The studies were conducted at commercial vineyards in the San Joaquin Valley and in the Paso Robles region, CA, with Cabernet Sauvignon as the cultivar. Water deficits were imposed at either $50 \%$ (moderate deficit) or $\mathbf{2 5 \%}$ (severe deficit) of standard irrigation (the control) for a period of 3 or 6 weeks and initiated at berry set, leafhopper egg hatch, or veraison. Deficit irrigation decreased berry weight by $16.1 \%$ at the San Joaquin Valley site (Aliso) and $11.7 \%$ at one of the Paso Robles sites (Frankel) but did not differ at the other site (Steinbeck). Yield was decreased by the deficits by $18.1 \%$ at Aliso, $26.7 \%$ at Frankel 2001 (but not 2002), and $24 \%$ at Steinbeck. Wine color density was increased by $21.8 \%$ at Aliso, 34.4\% at Frankel 2001 (but not 2002), and did not differ at Steinbeck. Soluble solids did not differ among treatments at any site. There was no difference in berry weight, yield, or color between the moderate and severe deficits. It appears that in central California, RDI such as these are likely to reduce yield but are only one factor among many variables affecting quality such as wine color.
\end{abstract}

In perennial fruit and nut cropping systems, water can be applied at a reduced rate during a defined phenological period while maintaining standard irrigation during the rest of the season (Chalmers et al., 1981). This has come to be known as RDI and has received a great deal of attention and research focus. The potential advantages of RDI are in improvements in shoot-to-fruit load ratios (Iniesta et al., 2009; Mitchell et al., 1984), water efficiency or productivity (Cui et al., 2009; Egea et al., 2010; Garcia-Tejero et al., 2010), and fruit quality (Garcia-Tejero et al., 2010; Papenfuss and Black, 2010). The main potential disadvantage is on fruit production, although results of RDI on yield have been mixed. Some studies showed a neutral effect (Cui et al., 2009; Papenfuss and Black, 2010),

Received for publication 9 Apr. 2012. Accepted for publication 11 June 2012.

Thanks to cooperators Martin Britz, Kip Green, and Gurmit Singh of Britz Farming (Aliso Vineyard); Warren Frankel at Frankel Vineyards; and Tim Lindquist and Howie Steinbeck at Steinbeck Vineyards. Field and laboratory assistance was provided by students Catherine Albers, Christopher Boisseranc, Paul Frankel, Bryce Gross, Jo Harper, Alfredo Koch, Rachel Power, Kevin Robertson, and Dory Wachtel. We are grateful to the the California Agricultural Technology Institute (CATI) at California State University, Fresno, the California State University Agricultural Research Initiative (ARI), and the Viticulture Consortium for funding these studies.

${ }^{1}$ To whom reprint requests should be addressed; e-mailmcostell@calpoly.edu. some resulted in yield decreases (Egea et al., 2010; Iniesta et al., 2009), and others found yield increases (Chalmers et al., 1986; Mitchell et al., 1984).

On wine grapes, RDI is distinguished from partial root zone drying, in which the deficit variable is not one of time, but of space, as applied water is alternated from one side of the vine to the other (Dry and Loveys, 1998). The timing of RDI on grapes has typically involved imposing the deficit from the grapevine phenological periods of berry set to veraison or veraison to ripeness (harvest) (Matthews and Anderson, 1988; Matthews et al., 1987), berry set to harvest (Acevado-Opazo et al., 2010; Chaves et al., 2007; dos-Santos et al., 2007; Shellie, 2006), and, less often, budbreak to bloom (Goodwin and Jerle, 1989) or budbreak to veraison (Hamman and Dami, 2000). Grape berry development occurs in three phases: post-berry set to veraison (rapid cell division followed by cell enlargement), a lag phase (cessation of cell enlargement and initiation of sugar accumulation), and, finally, veraison to ripeness (cell enlargement and initiation of anthocyanin accumulation) (DeLuc et al., 2007). Which phenological period the deficit is imposed in should have a distinct effect. Matthews and Anderson (1987) and Matthews et al. (1988) found that deficits imposed pre-veraison or post-veraison increased anthocyanins and other phenolics, produced smaller berries and reduced yield, but the effects on berry size and yield were more pronounced with pre-veraison compared with post-veraison deficit. McCarthy (1997) found that the greatest reduction on yield was when deficit was initiated just after bloom but before berry set and compared with the standard irrigation, pre-veraison and post-veraison lowered berry size, but there was little difference between these two periods. (Acevado-Opazo et al., 2010) found that RDI imposed between berry set and veraison or harvest increased concentration of anthocyanins and decreased berry diameter (but not berry weight), but only with a deficit intensity of $26 \%$ or less but not that of $\approx 50 \%$ of the standard irrigation.

On cultivated grape in California, it is common practice to irrigate at $\approx 100 \%$ of evapotranspiration $\left(1.0 \mathrm{ET}_{\mathrm{c}}\right)$ or more from 4 to 6 weeks after budbreak until just before harvest. However, Williams et al. (2010) showed that on Thompson Seedless, seasonwide irrigation at $0.80 \mathrm{ET}_{\mathrm{c}}$ can take place with no significant yield loss. To evaluate the impact of RDI on leafhopper density (primarily Erythroneura elegantula Osborn), we imposed RDI of either $50 \%$ or $25 \%$ of standard irrigation during second-generation leafhopper development, which about corresponds to the period between berry set and veraison. Erythroneura spp. overwinter as adults and begin feeding on grape tissue shortly after budbreak in the spring (late March to early April) (Costello, 2011). After mating, females lay eggs within the leaves. The first-generation nymphs hatch, develop through five stages (instars), and in the Paso Robles region of California, molt to adulthood by early to mid-June. Second-generation nymphal hatch is typically mid- to late July. Erythroneura spp. are sensitive to vine water status (Daane and Williams, 2003), and we have shown that RDI during second-generation nymphal development resulted in a significant decrease in leafhopper nymphal density (Costello, 2008; Costello and Veysey, 2012). We present the results of these studies on fruit production and wine color as an indicator of quality. Water application and stomatal conductance $\left(g_{\mathrm{S}}\right)$ results from one of the study sites and years (Frankel in 2001) are presented here; otherwise, these data can be found in Costello (2008) and Costello and Veysey (2012).

\section{Materials and Methods}

Details of experimental design and cultural practices for the Aliso and Frankel vineyards are in Costello (2008) and for the Steinbeck vineyard in Costello and Veysey (2012), but a summary is presented here. The study sites were mature, commercial vineyards located in central California. The Aliso vineyard was located in Madera County with a mean annual rainfall of $204 \mathrm{~mm}$ and midsummer (July through August) mean high and low temperatures 35.5 and $16.3{ }^{\circ} \mathrm{C}$, respectively. The Frankel and Steinbeck vineyards were located in San Luis Obispo County with mean annual rainfall $373 \mathrm{~mm}$ and midsummer mean high and temperatures 33.4 and $10.8^{\circ} \mathrm{C}$, respectively. The cultivar at all of the sites was 'Cabernet Sauvignon' with a cordon-trained, spur-pruned system but in 
Winter 2001-02, the vines at the Frankel site were retrained to a head-trained, cane-pruned system. At Steinbeck, the study plots were moved from the southwest corner of the vineyard (2002) to the northwest (2003), where soil type was less variable.

Each experiment was designed as a randomized complete block with treatments replicated four times. At the Frankel and Steinbeck sites, the deficit treatments were undertaken to reduce the control irrigation to $50 \%$ or $25 \%$ of standard irrigation, which was close to $1.0 \mathrm{ET}_{\mathrm{c}}$; at Aliso, only the $50 \%$ deficit was undertaken. These will hereafter be referred to as moderate $(50 \%)$ or severe $(25 \%)$ deficit. At the Steinbeck site, an additional split plot treatment varying the duration of the deficit (3 weeks vs. 6 weeks) was included. Deficit irrigation typically was initiated at berry set and maintained until veraison, although at the Aliso site, two variations of this period were included: leafhopper egg hatch (eclosion) to veraison and veraison to harvest. Deficit treatments were compared with a control based on the standard irrigation rate set by the vineyard manager at each site, who was assumed to be irrigating 0.8 to $1.0 \mathrm{ET}_{\mathrm{c}}$ throughout the season. The control irrigation estimation for the period of deficit was $0.89 \mathrm{ET}_{\mathrm{c}}$ at Aliso and $0.92 \mathrm{ET}_{\mathrm{c}}$ at Frankel in 2002 (Costello, 2008) and at Steinbeck $0.92 \mathrm{ET}_{\mathrm{c}}$ and $0.94 \mathrm{ET}_{\mathrm{c}}$ in 2002 and 2003, respectively (Costello and Veysey, 2012). Estimated control and deficit treatment water applied at Frankel in 2001 as in Table 1.

At each site, deficits were induced for a period of $\approx 6$ weeks, and at Steinbeck, a treatment was added to compare 3-week duration with the 6-week duration. At Aliso, three deficit initiation treatments were used: berry set (1 June), leafhopper egg hatch (eclosion) (29 June), and veraison (20 July), and each was imposed for 6 weeks. At Frankel in 2001, the deficits were initiated on 28 June and imposed until 9 Aug.; at Frankel in 2002, the deficits were initiated on 20 June until 1 Aug. At Steinbeck, deficit initiation took place on 21 June in 2002 and 2003 and imposed until either 12 July (3-week deficit) or 2 Aug. (6-week deficit).

Before the imposition of the deficit irrigation treatments, all vines in the study area were watered according to each grower's irrigation schedule. After the deficit, irrigation was set to $80 \%$ of the grower standard at Aliso and to $100 \%$ of the grower standard at Frankel and Steinbeck.
Stomatal conductance (Frankel in 2001) was measured with an LI-6200 $\mathrm{CO}_{2}$ porometer (LI-COR, Lincoln, NE). Leaves selected for measurement were mature and in full sun.

Grapes were harvested on 17 Sept. at Aliso, 30 Sept. at Frankel 2001, 1 Oct. at Frankel 2002, 8 Oct. at Steinbeck 2002, and 3 Oct. at Steinbeck 2003. Fruit was harvested and weighed from four vines per plot at Aliso or four cordons per plot or subplot at Frankel or Steinbeck. We took berry samples $(\approx 100$ berries per plot at Aliso, 50 per plot at Frankel, and 80 per plot at Steinbeck) for estimates of berry sugar and size. Berry sugar was measured as soluble solids ( ${ }^{\circ}$ Brix) with a temperature-compensating refractometer (Leica ${ }^{\circledR}$, Buffalo Grove, IL), and berries were weighed en total and then divided by the number of berries for estimated weight per berry.

Wine was made by processing the grapes through a stemmer/crusher, adding potassium metabisulfite and inoculating with yeast, fermenting in open-topped vessels covered with cheesecloth, and pressed when degrees balling were close to zero. The must was then pressed in a basket press and allowed to finish in a glass carboy. The wine was racked, and samples were analyzed for color using a spectrophotometer (Ivyland, PA).

Most data were log-transformed, except for color, which was transformed by reflect and inverse transformation. All data were analyzed by analysis of variance (ANOVA) with mean separation by Tukey's honestly significant difference (SAS Institute, 2010). Differences were considered statistically significant at $P<0.05$.

For the Frankel yield data, there was a significant year*treatment interaction $(\mathrm{F}=$ 11.93 , $\mathrm{df}=2,42, P<0.001)$, so each year's data were analyzed separately.

\section{Results}

Applied water. At Frankel in 2001, the estimated $\mathrm{ET}_{\mathrm{c}}$ for the period between $30 \mathrm{Apr}$. and 1 Oct. was $343.9 \mathrm{~mm}$, and for the same period, the control received an estimated $352.0 \mathrm{~mm}\left(102 \%\right.$ of estimated $\left.\mathrm{ET}_{\mathrm{c}}\right)$. Estimated seasonal water use was $244.6 \mathrm{~mm}$ for the moderate deficit treatment and $194.3 \mathrm{~mm}$ for the severe deficit treatment. Estimated standard irrigation for the deficit period was $0.89 \mathrm{ET}_{\mathrm{c}}$ at Aliso and $0.92 \mathrm{ET}_{\mathrm{c}}$ at Frankel in
2002 (Costello, 2008) and $0.92 \mathrm{ET}_{\mathrm{c}}$ and 0.94 $\mathrm{ET}_{\mathrm{c}}$ at Steinbeck 2002 and 2003, respectively.

Stomatal conductance. At Frankel in 2001, over the 6-week course of the deficit (5 July to 9 Aug.), $g_{\mathrm{S}}$ averaged $0.538,0.356$, and $0.361 \mathrm{~mol} \mathrm{CO} 2 / \mathrm{m}^{2} / \mathrm{sec}$ in the control, moderate deficit, and severe deficit treatments, respectively, a reduction of $\approx 28 \%$ in the deficit treatments compared with the control (repeated-measures ANOVA contrast $\mathrm{F}=$ 21.99, df $=1,31, P<0.01)$ but not a significant difference between the two deficit treatments (repeated-measures ANOVA contrast $\mathrm{F}=0.51, \mathrm{df}=1,31, P=0.48)$. In the post-deficit period, $g_{\mathrm{S}}$ was equivalent in all treatments on 16 Aug. and was again significantly different from 23 Aug. to 7 Sept. with readings averaging $0.293,0.16$, and $0.288 \mathrm{~mol} \mathrm{CO}_{2} / \mathrm{m}^{2} / \mathrm{sec}$ in the control, moderate, and severe deficit treatments, respectively, with the moderate deficit $44.9 \%$ lower than the severe deficit and the control (repeated-measures ANOVA contrast $\mathrm{F}=$ 17.66, $\mathrm{df}=1,31, P<0.01$ ).

Berry weight and soluble solids. At Aliso, the deficit treatments reduced berry weight by $16.1 \%$ overall (Tables 1 and 2), but there was no difference when comparing deficit initiation at pre-veraison with veraison nor when comparing deficit initiation at berry set with leafhopper egg hatch (Tables 1 and 2). Soluble solids at harvest averaged 23.56 ${ }^{\circ}$ Brix among treatments and did not differ significantly between deficit treatments and the control or among deficit treatments (Tables 1 and 2).

At Frankel, average ${ }^{\circ}$ Brix was 25.06 in 2001 and 22.70 in 2002 (Table 3) with no significant difference among treatments in either year (Table 4). Average berry weight was 0.93 in 2001 and 1.18 in 2002 (Table 3 ), again with no significant difference among treatments (Table 4).

At Steinbeck, there was a significant overall effect on berry weight with the deficit treatments $11.7 \%$ lower than the control (Tables 5 and 6) but no difference between the moderate and severe deficits. There was no significant effect of duration (Tables 5 and 6 ) with no interaction between duration and intensity $(\mathrm{F}=3.22$, $\mathrm{df}=1,6, P=0.1231)$. There was no effect of intensity or duration on ${ }^{\circ}$ Brix (Tables 5 and 6 ) with no interaction between time and intensity $(\mathrm{F}=3.42, \mathrm{df}=1$, 6, $P=0.1140$ ).

Yield. At Aliso, the overall ANOVA was significant (Table 2) with the deficit treatments lowering yield by $18.1 \%$ compared with the control (Tables 1 and 2). Yield for the deficit treatment initiated at leafhopper egg hatch (29 June) was 20.5\% lower than the deficit initiated at berry set (1 June) (Tables 1 and 2), but there was no significant difference between the deficits initiated pre-veraison (i.e., at either berry set or leafhopper egg hatch) and the deficit initiated at veraison (Tables 1 and 2)

At Frankel there was a significant effect on yield in 2001 but not in 2002 (Tables 3 and 4). In 2001, the deficit irrigation treatments reduced yield by $26.7 \%$ compared with the

\begin{tabular}{lcccc}
\multicolumn{1}{c}{$2000 .^{\mathrm{z}}$} & & & \\
\hline $\begin{array}{l}\text { Deficit treatment } \\
\text { initiation }\end{array}$ & $\begin{array}{c}\text { Yield } \\
(\mathrm{kg} / \mathrm{vine})\end{array}$ & $\begin{array}{c}\text { Soluble } \\
\left.\text { solids ( }{ }^{\circ} \mathrm{Brix}\right)\end{array}$ & $\begin{array}{c}\text { Berry } \\
\text { wt }(\mathrm{g})\end{array}$ & $\begin{array}{c}\text { Wine color } \\
(\text { absorbance } 420 \mathrm{~nm}+520 \mathrm{~nm})\end{array}$ \\
\hline Berry set & $7.53 \pm 0.35$ & $23.56 \pm 0.75$ & $1.20 \pm 0.04$ & $3.40 \pm 0.24$ \\
Leafhopper & $5.98 \pm 0.57$ & $23.62 \pm 0.24$ & $1.19 \pm 0.04$ & $3.31 \pm 0.03$ \\
$\quad$ egg hatch & & & & $3.31 \pm 0.31$ \\
Veraison & $8.10 \pm 0.65$ & $23.81 \pm 0.44$ & $1.20 \pm 0.04$ & $2.74 \pm 0.04$ \\
Control (grower & $9.19 \pm 0.459$ & $23.25 \pm 0.27$ & $1.43 \pm 0.03$ & \\
$\quad$ standard irrigation) & & & & \\
\hline
\end{tabular}

${ }^{\mathrm{z}}$ Deficits were $50 \%$ of the grower standard irrigation $\left(0.89 \mathrm{ET}_{\mathrm{c}}\right)$ and initiated at the indicated points for 6 weeks. 
control, but there was no significant difference between the moderate and severe deficit treatments (Tables 3 and 4).

At Steinbeck there was a significant overall effect of the repeated-measures ANOVA

Table 2. Aliso 2000 analysis of variance (ANOVA) for yield, soluble solids, berry weight, and wine color with comparisons among treatments using orthogonal contrasts. ${ }^{z}$

\begin{tabular}{|c|c|c|c|c|c|c|c|c|c|c|c|c|}
\hline & \multicolumn{3}{|c|}{ Yield } & \multicolumn{3}{|c|}{ Soluble solids } & \multicolumn{3}{|c|}{ Berry wt } & \multicolumn{3}{|c|}{ Wine color } \\
\hline & $\mathrm{F}$ & df & $P$ & $\mathrm{~F}$ & $\mathrm{df}$ & $P$ & $\mathrm{~F}$ & $\mathrm{df}$ & $P$ & F & df & $P$ \\
\hline ANOVA & 6.66 & 3,57 & $<0.001$ & 0.22 & 3,9 & 0.88 & 9.26 & 3,9 & 0.004 & 3.97 & 3,9 & 0.047 \\
\hline \multicolumn{13}{|l|}{ Contrast } \\
\hline Deficits vs. control & 9.60 & 1,57 & 0.003 & - & - & - & 27.75 & 1.9 & $<0.001$ & 11.52 & 1,9 & 0.008 \\
\hline $\begin{array}{l}\text { Pre-veraison vs. } \\
\text { post-veraison }\end{array}$ & 3.84 & 1,57 & 0.055 & - & - & - & 0.00 & 1.9 & 0.968 & 0.37 & 1,9 & 0.560 \\
\hline $\begin{array}{l}\text { Initiation at berry } \\
\text { set vs. initiation at } \\
\text { leafhopper egg hatch }\end{array}$ & 6.54 & 1,57 & 0.013 & - & - & - & 0.02 & 1.9 & 0.902 & 0.01 & 1,9 & 0.909 \\
\hline
\end{tabular}

${ }^{\mathrm{z}}$ The variable "deficits" pooled the data from the $50 \%$ of standard irrigation deficits at berry set, leafhopper egg hatch, and veraison. The variable "pre-veraison" pooled the data from the $50 \%$ of standard irrigation deficits at berry set and leafhopper egg hatch.

Table 3. Mean yield, soluble solids, berry weight, and wine color ( \pm SE of the mean), Frankel vineyard, $2001-02 .{ }^{z}$

\begin{tabular}{lcccc}
\hline $\begin{array}{l}\text { Yr and deficit } \\
\text { treatment }\end{array}$ & $\begin{array}{c}\text { Yield } \\
(\mathrm{kg} / \mathrm{vine})\end{array}$ & $\begin{array}{c}\text { Soluble solids } \\
\left({ }^{\circ} \text { Brix }\right)\end{array}$ & $\begin{array}{c}\text { Berry } \\
\mathrm{wt}(\mathrm{g})\end{array}$ & $\begin{array}{c}\text { Wine color } \\
(\text { absorbance } 420 \mathrm{~nm}+520 \mathrm{~nm})\end{array}$ \\
\hline 2001 & & & & \\
$\quad$ Moderate & $6.44 \pm 0.49$ & $25.0 \pm 0.36$ & $0.85 \pm 0.08$ & $4.59 \pm 0.40$ \\
$\quad$ Severe & $7.18 \pm 0.47$ & $24.9 \pm 0.26$ & $0.90 \pm 0.03$ & $4.31 \pm 0.66$ \\
$\quad$ Control & $9.30 \pm 0.55$ & $25.3 \pm 0.42$ & $1.03 \pm 0.06$ & $3.31 \pm 0.22$ \\
2002 & & & & \\
$\quad$ Moderate & $6.46 \pm 0.41$ & $23.25 \pm 1.01$ & $1.18 \pm 0.04$ & $3.03 \pm 0.15$ \\
$\quad$ Severe & $7.06 \pm 0.46$ & $21.75 \pm 1.08$ & $1.09 \pm 0.10$ & $2.99 \pm 0.24$ \\
$\quad$ Control & $5.68 \pm 0.51$ & $23.12 \pm 1.14$ & $1.28 \pm 0.11$ & $2.44 \pm 0.54$ \\
\hline
\end{tabular}

${ }^{\mathrm{z}}$ Deficits were $50 \%$ (moderate) or $25 \%$ (severe) of the grower standard irrigation $\left(1.02 \mathrm{ET}_{\mathrm{c}}\right.$ in 2001 and $0.92 \mathrm{ET}_{\mathrm{c}}$ in 2002) and initiated at berry set for 6 weeks.

Table 4. Frankel 2001-02 analysis of variance (ANOVA) for yield, soluble solids, berry weight, and wine color with comparisons among treatments using orthogonal contrasts in 2001. ${ }^{\mathrm{z}}$

\begin{tabular}{|c|c|c|c|c|c|c|c|c|c|c|c|c|}
\hline & \multicolumn{3}{|c|}{ Yield } & \multicolumn{3}{|c|}{ Soluble solids } & \multicolumn{3}{|c|}{ Berry wt } & \multicolumn{3}{|c|}{ Wine color } \\
\hline & $\mathrm{F}$ & $\mathrm{df}$ & $P$ & $\mathrm{~F}$ & $\mathrm{df}$ & $P$ & $\mathrm{~F}$ & $\mathrm{df}$ & $P$ & $\mathrm{~F}$ & $\mathrm{df}$ & $P$ \\
\hline 2001 & & & & & & & & & & & & \\
\hline ANOVA & 8.30 & 2,42 & $<0.001$ & 0.27 & 2,6 & 0.769 & 2.43 & 2,6 & 0.168 & 5.34 & 2,6 & 0.046 \\
\hline Contrast & & & & & & & & & & & & \\
\hline Deficits vs. c & 15.26 & 1,42 & $<0.001$ & - & - & - & - & - & - & 9.50 & 1,6 & 0.021 \\
\hline $\begin{array}{l}\text { Moderate deficit } \\
\text { vs. severe deficit }\end{array}$ & 1.34 & 1,42 & 0.253 & - & - & - & - & - & - & 1.19 & 1,6 & 0.317 \\
\hline 2002 & & & & & & & & & & & & 018 \\
\hline ANC & 2.99 & 2,42 & 0.061 & 0.42 & 2,6 & 0.677 & 0.86 & 2,6 & 0.470 & 2.27 & 2,6 & 0.184 \\
\hline
\end{tabular}

${ }^{\mathrm{z} B e c a u s e}$ the overall ANOVA was not significant for any variable in 2002, contrasts are omitted. The variable "deficits" pooled the data from the moderate and severe deficit treatments.

Table 5. Mean yield, soluble solids, berry weight, and wine color ( \pm SE of the mean), Steinbeck vineyard, 2002-03. ${ }^{\mathrm{z}}$

\begin{tabular}{lcccc}
\hline $\begin{array}{l}\text { Yr and deficit intensity } \\
\text { and duration }\end{array}$ & $\begin{array}{c}\text { Yield } \\
(\mathrm{kg} / \text { vine })\end{array}$ & $\begin{array}{c}\text { Soluble solids } \\
\left({ }^{\circ} \text { Brix }\right)\end{array}$ & $\begin{array}{c}\text { Berry } \\
\text { wt }(\mathrm{g})\end{array}$ & $\begin{array}{c}\text { Wine color } \\
\text { (absorbance 420 } \mathrm{nm}+520 \mathrm{~nm})\end{array}$ \\
\hline 2002 & & & & \\
$\quad$ Moderate & $10.28 \pm 0.93$ & $22.66 \pm 0.641$ & $0.971 \pm 0.028$ & $2.34 \pm 0.10$ \\
$\quad$ Severe & $10.53 \pm 0.53$ & $22.83 \pm 0.421$ & $0.953 \pm 0.050$ & $2.12 \pm 0.05$ \\
Control & $12.95 \pm 1.02$ & $22.00 \pm 0.695$ & $1.006 \pm 0.049$ & $2.37 \pm 0.48$ \\
3 weeks & $10.23 \pm 0.52$ & $22.16 \pm 0.380$ & $0.943 \pm 0.028$ & - \\
6 weeks & $10.57 \pm 0.93$ & $23.33 \pm 0.557$ & $0.981 \pm 0.049$ & - \\
2003 & & & & $2.09 \pm 0.18$ \\
Moderate & $4.34 \pm 0.36$ & $20.91 \pm 0.568$ & $0.891 \pm 0.051$ & $2.14 \pm 0.14$ \\
Severe & $4.86 \pm 0.43$ & $22.16 \pm 0.440$ & $0.915 \pm 0.050$ & $2.14 \pm 0.19$ \\
Control & $6.76 \pm 0.52$ & $22.41 \pm 0.757$ & $1.106 \pm 0.036$ & $2.14 \pm 0.14$ \\
3 weeks & $4.63 \pm 0.39$ & $21.00 \pm 0.683$ & $0.890 \pm 0.053$ & $2.09 \pm 0.18$ \\
6 weeks & $4.54 \pm 0.41$ & $22.08 \pm 0.300$ & $0.916 \pm 0.048$ & \\
\hline
\end{tabular}

${ }^{{ }^{2}}$ Deficit intensities were $50 \%$ (moderate) or $25 \%$ (severe) of the grower standard irrigation $\left(0.92 \mathrm{ET}_{\mathrm{c}}\right.$ in 2002 and $0.94 \mathrm{ET}_{\mathrm{c}}$ in 2003) and initiated at berry set for durations of either 3 or 6 weeks. (i.e., the 6-week deficit vs. the 3-week deficit) (Tables 5 and 6).

Wine color. Wine made from the grapes at Aliso increased color by $21.8 \%$ when all of the deficits were compared with control, but there was no difference in pre-veraison vs. post-veraison deficits nor deficits initiated at berry set vs. egg hatch (Tables 1 and 2). At Frankel in 2001, the deficit treatments improved color by $34.4 \%$ compared with control, but there was no difference between the moderate and severe deficits (Tables 3 and 4). However, there was no significant difference among treatments in color at Frankel 2002 (Tables 3 and 4) nor at Steinbeck (Tables 5 and 6).

\section{Discussion}

The trend from these studies is that the RDI treatments decreased yield by an average of $22.9 \%$ compared with the controls for four of the five studies. The exception was Frankel in 2002, which might be explained by the retraining from spur to cane pruning done in the winter of 2001-02. 'Cabernet Sauvignon' is known for highest fruitfulness at the base and distal end of the cane (McLoughlin et al., 2011), and this switch to canes may have masked the effects of deficit irrigation in the first year after the retraining. In recent studies, reports on the effect on yield of RDI from berry set to veraison, veraison to harvest, or berry set to harvest have primarily shown no significant declines (Azevado-Opazo et al., 2010; Chaves et al., 2007; dos Santos et al., 2007; Keller et al., 2008), although (Shellie 2006 ) reported an $\approx 35 \%$ yield reduction at $0.35 \mathrm{ET}_{\mathrm{c}}$.

Although in the current studies the initiation of the deficits only varied at one site (Aliso), the effect there on yield was similar to McCarthy (1997), who found that deficits initiated pre- or post-veraison were similar in their impact on yield; however, McCarthy (1997) also found that pre-veraison deficit produced smaller berries than post-veraison deficit, which was not found at Aliso.

Berry weight was affected by the RDI treatments at Aliso and Steinbeck but was not significantly different at Frankel. These variable results are not uncommon among RDI studies, several of which found smaller berries in some but not all study years (Keller et al., 2008; McCarthy, 1997; Shellie, 2006), although Matthews and Anderson (1988) found a consistently negative effect, and AzevadoOpazo et al. (2010) found a consistent noneffect. In the current studies, berry weight is the most reasonable explanation for yield decline. The only other way that yield could have been reduced was through fewer berries per cluster, but because each of the years in which yield was reduced was a single-year study, there was no carryover effect from the previous year on bud fruitfulness, and because RDIs were initiated after berry set, the number of berries per cluster among treatments should not have been affected.

The lack of difference in berry weight or yield between intensity deficits (moderate vs. 
Table 6. Steinbeck, 2002-03, repeated-measures analysis of variance (ANOVA), using year as the repeated-measures variable, for yield, soluble solids, berry weight, and wine color with comparisons among treatments using orthogonal contrasts. ${ }^{\mathrm{z}}$

\begin{tabular}{|c|c|c|c|c|c|c|c|c|c|c|c|c|}
\hline & \multicolumn{3}{|c|}{ Yield } & \multicolumn{3}{|c|}{ Soluble solids } & \multicolumn{3}{|c|}{ Berry wt } & \multicolumn{3}{|c|}{ Color } \\
\hline & $\mathrm{F}$ & df & $P$ & $\mathrm{~F}$ & df & $P$ & $\mathrm{~F}$ & df & $P$ & $\mathrm{~F}$ & df & $P$ \\
\hline INOVA deficit intensity & 9.75 & 2,67 & $<0.001$ & 0.64 & 2,13 & 0.545 & 7.50 & 2,13 & 0.007 & 1.48 & 4,23 & 0.24 \\
\hline ontrast & & & & & & & & & & & & \\
\hline Deficits v & 18.58 & 1,67 & $<0.001$ & - & - & - & 15.00 & 1,13 & 0.002 & - & - & - \\
\hline $\begin{array}{l}\text { Moderate deficit } \\
\text { vs. severe deficit }\end{array}$ & 0.93 & 1,67 & 0.338 & - & - & - & 0.00 & 1,13 & 0.960 & - & - & - \\
\hline ANOVA duration & 0.05 & 1,40 & 0.832 & 0.71 & 1,6 & 0.431 & 4.57 & 1,6 & 0.076 & 0.57 & 9,15 & 0.7 \\
\hline
\end{tabular}

"The variable "deficits" pooled the data from the moderate and severe deficit treatments. Because the overall ANOVA was not significant for duration, contrasts are omitted.

severe, Frankel and Steinbeck vineyards) or duration (3-week vs. 6-week deficits, Steinbeck vineyard only) was not expected. Although few studies on RDI have varied intensity, Hamman and Dami (2000) found a significant yield difference between $50 \%$ and $25 \%$ of standard irrigation when these RDIs were imposed between budbreak and veraison. Inconsistencies in $g_{\mathrm{S}}$ readings suggest that there may not always have been separation between the two RDI treatments. Although $g_{\mathrm{S}}$ was lowered by RDI treatments at Frankel in 2001 and Steinbeck in 2003 (Costello and Veysey, 2012), in neither of these studies do $g_{\mathrm{S}}$ readings show a separation between the moderate and severe deficits. However, at Frankel in 2002, the severe deficit was reduced by $13.1 \%$ compared with the moderate deficit (Costello, 2008), and at Steinbeck in 2002 , the RDI treatments reduced $g_{\mathrm{S}}$ by $\approx 20 \%$ in the severe deficit compared with the moderate deficit treatment (Costello and Veysey, 2012). It may also be that differences in soil water storage (from winter rains) and $\mathrm{ET}_{\mathrm{o}}$ during the period of deficit differed enough that the effects of the deficit varied among years and made it difficult to separate the two RDIs. Interestingly, these variations may be related to seasonal differences in rainfall, because 2002 was a drier year (rainfall of $212 \mathrm{~mm}$ ) than either 2001 (392 mm) or 2003 $(349 \mathrm{~mm})$. If this does explain the variation among years in $g_{\mathrm{S}}$, the conditions still did not translate to differences in berry weight or yield.

The effect on wine color was also not consistent with RDI treatments, increasing optical density readings in just two of the five studies (Aliso and Frankel in 2001). It is logical to think that smaller berries, because of higher surface area to volume ratios, would result in better color and phenolic concentration. However, although smaller berries have higher skin/pulp ratios, anthocyanin and phenolic concentrations are independent of berry surface area (Matthews et al., 1990; Roby et al., 2004). More recently, it has been recognized that water stress can influence genetic transcription factors, which influence the production of phytochemicals such as phenolics (Castellarin et al., 2007). Results of other studies on grape berry or wine chemistry have also been inconsistent. In studies on RDI of just one year, Hamman and Dami (2000) found improved wine color and Ojeda et al. (2002) found increased phenolic concentration in berry skin, but dos Santos et al. (2007) found no change in berry phenolics. In multiyear studies, Chaves et al. (2007) reported significant increases in berry anthocyanin concentration in one of three study years, Keller et al. (2008) found that pre-veraison deficit resulted in poorer juice color, but postveraison deficit was no different from standard irrigation, and Matthews et al. (1990) found that pre-veraison deficit produced better wine color, whereas post-veraison deficit was not different from the control. This variability indicates that other environmental factors such as soil or weather may play an equal or greater role on berry phytochemical quality and concentration than water stress. Note that within the current studies at Steinbeck, when contrasting years with well below average and near average rainfall (2002 vs. 2003, respectively), there was still no effect on wine color under RDI.

For the California practitioner, the decision to undertake RDI has benefits and drawbacks. It is likely that with the imposition of RDI between berry set and veraison or veraison and harvest, lower yields will be experienced. In these studies, these yield declines ranged from $18 \%$ to $27 \%$ compared with standard irrigation. Benefits include a reduction in leafhopper density (Costello, 2008), although indications are that for this to be sustained, the deficit needs to be maintained for as long as lower leafhopper density is desired (Costello and Veysey, 2012). In regions of California where leafhoppers are pests, this benefit might include a reduction in frequency of insecticide application. Another benefit is a decrease in water use, as at the Frankel site the moderate and severe treatments resulted in lowered water application by $30 \%$ and $45 \%$, respectively, compared with the standard irrigation. Finally, the benefit of improvement in wine quality, using color as an indicator, is less certain and appears to be subject to environmental variables besides water stress.

\section{Literature Cited}

Acevado-Opazo, C., S. Ortega-Farias, and S. Fuentes. 2010. Effects of grapevine (Vitis vinifera L.) water status on water consumption, vegetative growth and grape quality: An irrigation scheduling application to achieve regulated deficit irrigation. Agr. Water Mgt. 97: 956-964.

Castellarin, S.D., M.A. Matthews, G. Di Gaspero, and G.A. Gambetta. 2007. Water deficits accelerate ripening and induce changes in gene expression regulating flavonoid biosynthesis in grape berries. Planta 227:101-112.

Chalmers, D.J., G. Burge, P.H. Jerie, and P.D. Mitchell. 1986. The mechanism of regulation of Bartlett pear fruit and vegetative growth by irrigation withholding and regulated deficit irrigation. J. Amer. Soc. Hort. Sci. 111:904-990.

Chalmers, D.J., P.D. Mitchell, and L. van Heek 1981. Control of peach tree growth and productivity by regulated water supply, tree density, and summer pruning. J. Amer. Soc. Hort. Sci. 106:307-312.

Chaves, M.M., T.P. Santos, C.R. Souza, M.F. Ortuño, M.L. Rodrigues, C.M. Lopes, J.P. Maroco, and J.S. Pereira. 2007. Deficit irrigation in grapevine improves water-use efficiency while controlling vigour and production quality. Ann. Appl. Biol. 150:237-252.

Costello, M.J. 2008. Regulated deficit irrigation and density of Erythroneura spp. (Hemiptera: Cicadellidae) on grape (Vitis vinifera). J. Econ. Entomol. 101.4:1287-1294.

Costello, M.J. 2011. Insects and mites in organic vineyard systems, p. 111-130. In: McGourty, G.T., J. Ohmart, and D. Chaney (eds.). Organic winegrowing manual. University of California, Agriculture and Natural Resources, Oakland, CA.

Costello, M.J. and S.T. Veysey. 2012. Influence of intensity and duration of regulated deficit irrigation on Erythroneura elegantula (Hemiptera: Cicadellidae) on grape (Vitis vinifera). J. Econ. Entomol. 105:1293-1301.

Cui, N., T. Du, F. Li, L. Tong, S. Kang, M. Wang, X. Liu, and Z. Li. 2009. Response of vegetative growth and fruit development to regulated deficit irrigation at different growth stages of pear-jujube tree. Agr. Water Mgt. 96:12371246

Daane, K.M. and L.E. Williams. 2003. Manipulating vineyard irrigation amounts to reduce insect pest damage. Ecol. Appl. 13:1650-1666.

DeLuc, L.G., J. Grimplet, M.D. Wheatley, R.L. Tillett, D.R. Quilici, C. Osborne, D.A. Schooley, K.A. Schlauch, J.C. Cushman, and G.R. Cramer. 2007. Transcriptomic and metabolite analyses of Cabernet Sauvignon grape berry development. BMC Genomics 8:429.

dos Santos, T.P., C.M. Lopes, M.L. Rodrigues, C.R. de Souza, J.M. Ricardo-da-Silva, J.P. Maroco, J.S. Pereira, and M.M. Chavesdos. 2007. Effects of deficit irrigation strategies on cluster microclimate for improving fruit composition of Moscatel field-grown grapevines. Sci. Hort. 112:321-330.

Dry, P.R. and B.R. Loveys. 1998. Factors influencing grapevine vigour and the potential for control with partial rootzone drying. Aust. J. Grape Wine Res. 4:140-148.

Egea, G., P.A. Nortes, M.M. Gonzalez-Real, A. Baille, and R. Domingo. 2010. Agronomic response and water productivity of almond trees under contrasted deficit irrigation regimes. Agr. Water Mgt. 97:171-181.

Garcia-Tejero, I., R. Romero-Vicente, J.A. JimenezBocanegra, G. Martınez-Garcia, V.H. DuranZuazo, and J.L. Muriel-Fernandez. 2010. Response of citrus trees to deficit irrigation during different phenological periods in relation to yield, fruit quality, and water productivity. Agr. Water Mgt. 97:689-699.

Goodwin, I. and P. Jerle. 1989. Deficit irrigation of Chardonnay grapevines during flowering. Acta Hort. 240:275-278.

Hamman, R.A. and I.E. Dami. 2000. Effects of irrigation on wine grape growth and fruit quality. HortTechnology 10:162-168.

Iniesta, F., L. Testia, F. Orgaza, and F.J. Villalobosa. 2009. The effects of regulated and continuous 
deficit irrigation on the water use, growth and yield of olive trees. Eur. J. Agron. 30:258-265.

Keller, M., R.P. Smithyman, and L.J. Mills. 2008. Interactive effects of deficit irrigation and crop load on Cabernet Sauvignon in an arid climate. Amer. J. Enol. Viticult. 59:221-234.

Matthews, M.A. and M.M. Anderson. 1988. Fruit ripening in Vitis vinifera L.: Responses to seasonal water deficits. Amer. J. Enol. Viticult. 39:313-320.

Matthews, M.A., M.M. Anderson, and H.R. Schultz. 1987. Phenologic and growth responses to early and late season water deficits in Cabernet franc. Vitis 26:147-160.

Matthews, M.A., R. Ishii, M.M. Anderson, and M. O'Mahony. 1990. Dependence of wine sensory attributes on vine water status. J. Sci. Food Agr. 51:321-335.
McCarthy, M.G. 1997. The effect of transient water deficit on berry development of cv. Shiraz (Vitis vinifera L.). Aust. J. Grape Wine Res. 3:2-8.

McLoughlin, S.J., P.R. Petrie, and P.R. Dry. 2011. Impact of node position and bearer length on the yield components in mechanically pruned Cabernet Sauvignon (Vitis vinifera L.). Aust. J. Grape Wine Res. 17:129-135.

Mitchell, P.D., D.J. Chalmers, and P.H. Jerie. 1984. The effects of regulated water deficits on pear tree growth, flowering, fruit growth, and yield. J. Amer. Soc. Hort. Sci. 109:604606.

Ojeda, H., A. Andary, E. Kraeva, A. Carbonneau, and A. Deloire. 2002. Influence of pre- and postveraison water deficit on synthesis and concentration of skin phenolic compounds during berry growth of Vitis vinifera cv. Shiraz. Amer. J. Enol. Viticult. 53:261-267.
Papenfuss, K.A. and B.L. Black. 2010. Regulated deficit irrigation of 'Montmorency' tart cherry. HortScience 45:1437-1440.

Roby, G., J.F. Harbertson, D.A. Adams, and M.A Matthews. 2004. Berry size and vine water deficits as factors in winegrape composition: Anthocyanins and tannins. Aust. J. Grape Wine Res. 10:100-107.

SAS Institute. 2010. SAS/STAT user's guide, release 9.3 ed. SAS Institute, Cary, NC.

Shellie, K. 2006. Vine and berry response of Merlot (Vitis vinifera L.) to differential water stress. Amer. J. Enol. Viticult. 57:514-518.

Williams, L.E., D.W. Grimes, and C.J. Phene. 2010. The effects of applied water at various fractions of measured evapotranspiration on reproductive growth and water productivity of Thompson Seedless grapevines. Irrig. Sci. 28:233-243. 